\title{
The Plight of the Grey Seal in the Baltic
}

$$
\text { By Kai Curry-Lindahl }
$$

The grey seals in the Baltic, like those on the Farne Islands in Britain, are accused by the fishermen of serious damage to fisheries and nets. But unlike the British seals the Baltic ones are not only entirely unprotected, but bounties are paid for their destruction in Sweden and Finland, and their numbers are decreasing. Moreover, because of their accessibility on the ice where they are born, a high proportion of calves is killed each year, which seriously unbalances the population and could lead to a crash.

THE recent controversy in Great Britain about the grey seal Halichoerus grypus has been followed with interest in Sweden. For it raises questions of conservation practice and principles concerning a marine mammal which is decreasing in the Baltic at the same time as it is accused of doing heavy damage to fish and nets.

The two populations differ in several respects. In the Baltic there are no large concentrations of grey seals such as there are in some areas around the British coasts, for instance, in the Farne Islands, and the British population is about 37,000 while the Baltic population, for which there are no reliable figures, is estimated at between 5,000 and 10,000. Moreover, the British grey seals breed in September-November, the Baltic ones in February-March. The grey seal ranges widely in the Baltic, though scarcer in the northernmost parts of the Gulf of Bothnia. In general, it is more pelagic than the other two Baltic seals, the common seal Phoca vitulina and the ringed seal $P$. hispida, and is most often seen in the open sea or lying on the outer skerries off the coasts and archipelagoes. It is mainly sedentary, except during the breeding period in February-March, when both females and males make for the edge of the ice sheet, which in normal winters is in the Gulf of Bothnia, but in severe winters further south. After breeding they disperse again to the sea in the central and southern Baltic, returning to the skerries and ice sheets for moulting in April-May. But, in general the grey seal prefers to winter in the open sea, apparently because it is unable to keep holes open in thick ice for several months in the way that the ringed seal does.

Nowadays the breeding populations of the Baltic and Atlantic grey seals are separated geographically. The Atlantic colonies nearest to the Baltic are in the British Isles and off the Bay of Trondheim in Norway, where the grey seal has decreased tremendously during the last century. But it still occurs sparingly along the northern parts of the west coast of Sweden. We know that some of these grey seals are of British origin and some probably come from the Norwegian colonies. When they appear off the coasts of the Swedish provinces of Bohuslän and Halland, they are not far from the 


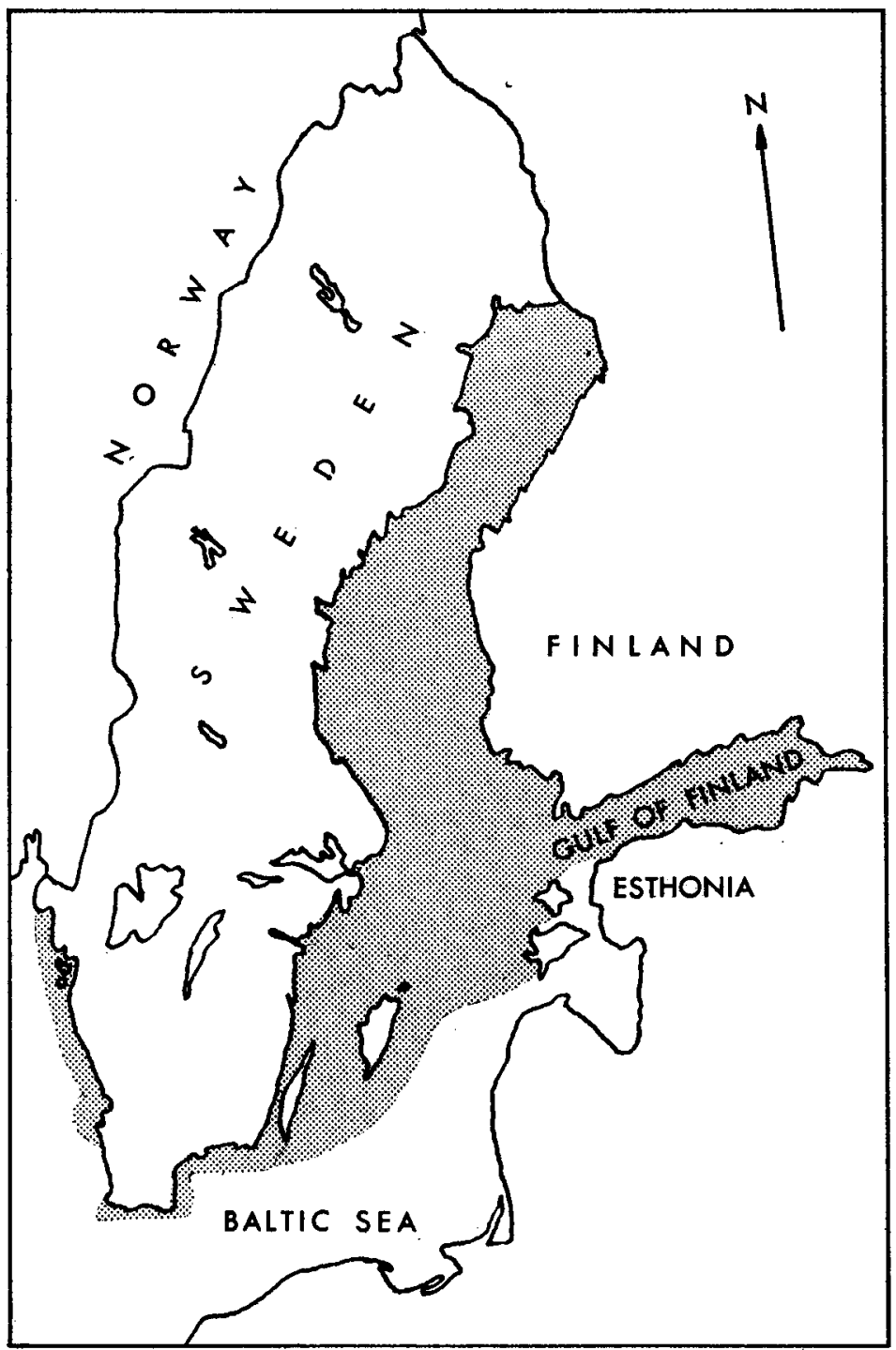

The Distribution of the Grey Seal in the Baltic Sea and the Gulf of Finland range of the grey seal in the south-west Baltic. This means that the two populations are not completely isolated from each other geographically, as they are biologically and physiologically, for their breeding seasons differ widely. However, a certain gene-flow between them cannot be entirely excluded through the individual adaptation of Atlantic stragglers to the climatic conditions in the Baltic or vice versa. We know, for instance, that 
reindeer from Scandinavia introduced into the southern hemisphere have in a few years changed their breeding seasons. Moreover, the grey seal has bred as recently as the latter part of the nineteenth century on the Danish island of Anholt in the Kattegat, where it was abundant 100 years ago but was exterminated by man. Its breeding season there was in DecemberJanuary, intermediate between the Atlantic populations (SeptemberNovember) and the Baltic ones (February-March). The Baltic breeding period is the same as that of the west Atlantic populations, and as far as we know there are no morphological differences between the Atlantic and Baltic grey seals. During the post-glacial period, about 8,000 years ago when the climate in the Baltic was warmer than it is now, the two populations were geographically isolated for about 2,000 years.

The fact that the Baltic and west Atlantic populations of the grey seal breed in late winter and mainly on the ice, whereas those living around the British Isles and Norway reproduce during the autumn on rocks and shores, is certainly due to adaptation to climatic conditions. Apparently it is advantageous for the Baltic grey seal to give birth to the calves in February-March when the drift ice has reached its maximal distribution and is starting to melt. Only rarely, during extremely mild winters, do grey seals breed on rocks. The newborn calf lies quite unprotected on the ice, usually close to the edge, which gives its mother easy access to the open water for feeding and escaping in case of danger. The calf's protection against enemies is its yellowish-white coat which makes it inconspicuous. One born at Skansen, the Zoological Garden of Stockholm-as far as I know the only grey seal born and raised by its mother in captivitymeasured $39 \cdot 37$ inches when a few hours old. The calf is suckled by its mother for about three weeks, increasing in weight by 4.40 pounds a day, which shows the extremely high nutritive value of the seal milk, and growing more in width than in length, so that after about three weeks it is almost barrel-shaped.

At the end of the suckling period, abandoned by its mother who seeks the company of the males for mating, the calf starts moving around on the ice. It can wander great distances, and sometimes even crosses the woods of islets and islands. Several times grey seal calves have got to the Swedish mainland, where they have been found far from the nearest marine ice. Of course, the drift of the ice may sometimes have carried them ashore. The calf can swim at two or three weeks old, but normally it does not take to the water until after the first moult is completed at four or five weeks. The shedding of the whitish woolly coat varies with the individual and takes only a few days; after that the calf is ready for the sea.

The Baltic grey seal is polygamous, and loosely organised harems seem to be formed on the ice around certain males. The breeding sites change, not only from one year to another depending on the variations in the ice situation in different winters, but also within the same breeding season, because the edge of the drift ice, where the calving and mating seals gather, is constantly shifting. This, unfortunately, makes it difficult to check the composition of the breeding colonies in the same way as has been done in Great Britain (Davies, 1949; Hewer, 1957, 1964), which is a pity because the rather large proportion of calves killed each year is probably 


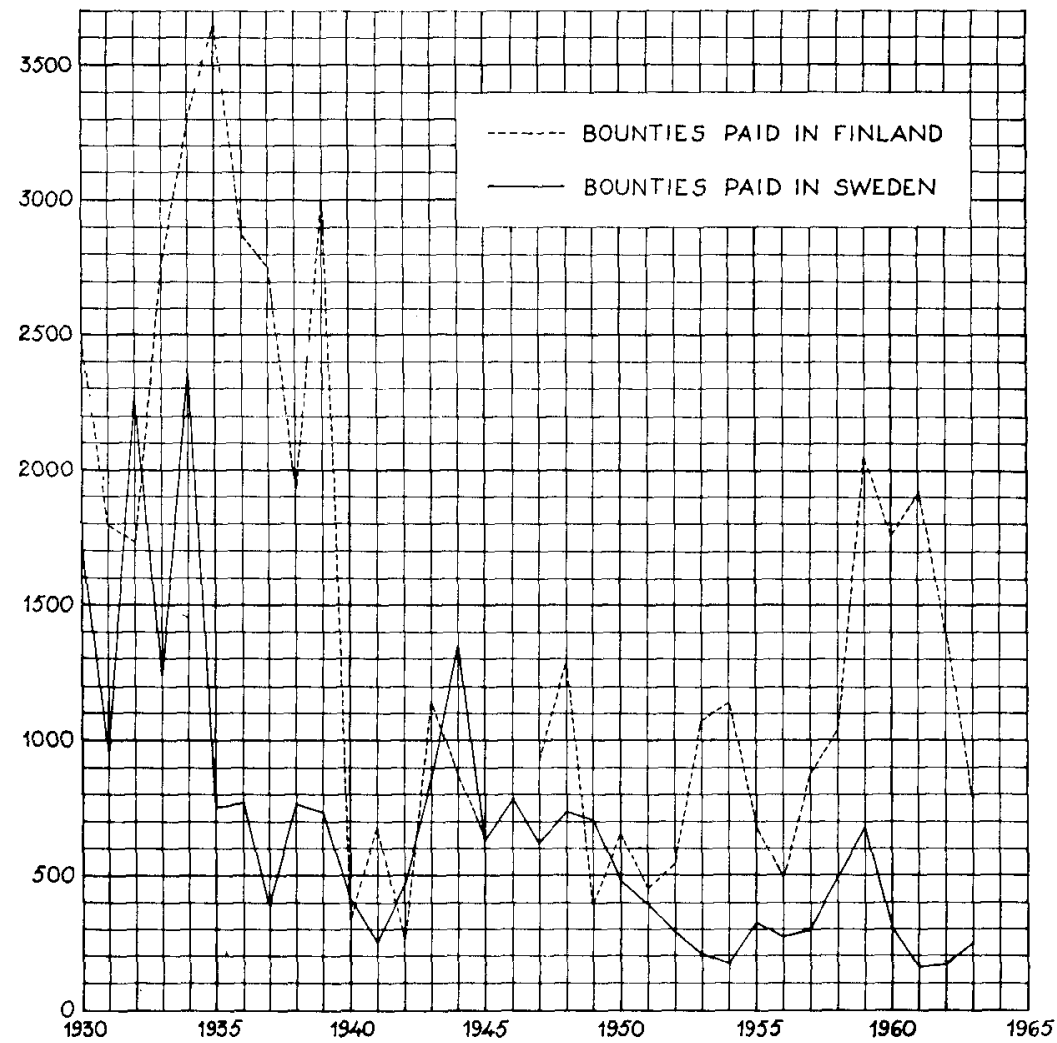

the cause of the rise in the mean age of the population. Since the grey seal reaches a considerable age (forty-three is the longevity record held by a bull at Skansen in Stockholm; Curry-Lindahl, 1963), it may take a considerable time before it becomes clear that numbers in certain years are so small that a crash might occur and the population be in danger of disappearing.

Unfortunately, there are no reliable population figures or estimates available from the Baltic as it has hitherto been impossible to make accurate counts from aircraft. The only figures which can be used are the numbers of seals killed each year, based on bounties. Taking the figures from Finland and Sweden together, we find that the numbers killed fluctuate considerably from one year to another, but there is a good correlation between the Swedish and Finnish curves. During the 1930's the combined figures vary from 2,696 to 5,668 (average 3,821); in the 1940 's from 726 to 2,215 (average 1,252); in the 1950's from 763 to 2,723 (average 1,006); and in 1960-63 from 1,020 to 2,066 (average 1,683).

The Finnish statistics are particularly valuable because they show the proportions of adults and calves. It is remarkable that between 1930-39, 
65 per cent killed in Finland were calves, an extremely high proportion. In the three succeeding decades the percentages dropped to 42,43 , and 41 respectively. No differentiated figures of the same kind are available from Sweden, but there are reasons to believe that the proportions of calves killed has been higher in Sweden than in Finland in the last twenty years. Between 1949 and 1963, Finnish statistics show 3,895 grey seal calves killed in the Baltic, an annual average of 260 . During the same period Swedish killings numbered 5,285 (both calves and adults). It is reasonable to assume that at least half of this number were calves, which makes an annual Swedish average of 176 calves killed. Hence the total annual average of calves killed for Finland and Sweden together during the last fifteen years is estimated at about 436 . Of course, grey seals are also killed by people from other countries in the Baltic, but numbers are presumably small compared with those of Finland and Sweden. In addition, ships from outside the Baltic may accidentally kill grey seals when sailing outside territorial waters. If an average of 436 calves are killed each year in Finland and Sweden, it means that at least 500 calves are born each year in the Baltic, and this is also the minimum figure for breeding cows.

\section{Cows Are More Vulnerable}

For adults the Finnish statistics show that 5,548 were killed in the period 1949-63. To this figure about half of the Swedish grey seals killed has to be added (the other half are calves), giving a total of 8,141 adults, and an average of 543 . We know nothing about the sex ratios of these seals. Probably most of the adults killed are cows, because they are more vulnerable than males due to hunting pressure during the calving and nursing season, when most hunting takes place along the edge of the ice.

The result of the high proportion of calves killed in the Baltic during the 1930 's, according to Bergman (1956), was that twenty years later the population along the western coast of Finland included an unusually large number of very old individuals, and this local situation is probably significant for the whole Baltic area, at least in the northern parts.

Based on the Swedish statistics Lockley (1954) estimated the Baltic grey seal numbers at about 5,000 animals, which Davies (1957) is inclined to think is a considerable underestimate. Lockley's estimate is quoted by Scheffer (1958) in his review of the Pinnipedia. Haglund (1961) makes a guess of about 10,000 animals. As, unfortunately, we know almost nothing about either the age-composition of the Baltic population or the proportion of animals killed (apart from calves) in relation to the stocks of mature and immature animals, it is impossible to draw any firm conclusions as to the population size.

The grey seal is not only totally unprotected in the Baltic but bounties are paid both in Finland and Sweden. The fishermen's organisations in these countries, claiming increased damage, have suggested that the bounties ought to be augmented to about $£ 2$ for adult seals and about $£ 1$ for calves killed before May 1st. Of course, the conservation organisations are against such a drastic step with a species which is declining in numbers, and long ago suggested to the Swedish government that bounties on seals 


\section{Grey seals killed in the Baltic Sea during the period 1930-1959 according to Finnish and Swedish statistics}

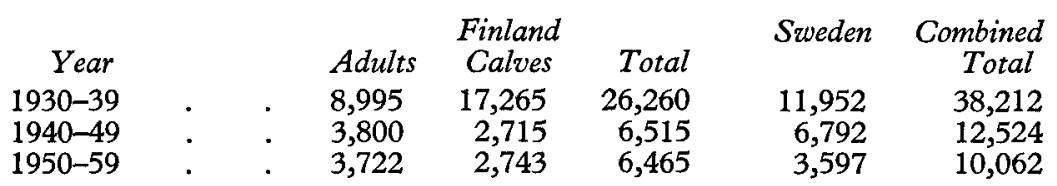

(and on other animals as well) should not be paid any longer. They also proposed a close season during the breeding period, and reserves for seals in some coastal areas.

It is difficult to distinguish the immediate effect of bounties on seal populations in Sweden, because the seals would probably be killed anyway. There is no longer any organised hunting on the ice, but there is considerable slaughter every spring when great numbers of calves are killed on the ice by the crews of ships and fishing boats passing along the edges of the drift ice, just when the calves are most vulnerable. In 1960, for example, fishermen from one Swedish trawler in the Baltic killed 119 calves on a single occasion.

Such a heavy toll of newborn calves as 41-65 per cent of all seals killed over a period of thirty-four years must have resulted in a strange agecomposition in the population, especially as it is possible that the majority of adults killed are cows. Bulls are known to be shorter-lived than cows in British waters (Hewer, 1964), but we do not know if this also holds true in the Baltic. Baltic grey seal cows usually reach sexual maturity at five years and bulls at six years. In general only one calf is born each year, but this rather slow reproduction rate is partly compensated by the fact that the grey seal has a long life and that cows continue to breed at least until 31-32 years old (Hewer, 1964).

In addition to direct killing, the intensified commercial, military and recreational traffic along the Baltic coasts disturbs the grey seals and there are hardly any quiet skerries now to which they can retreat in summer.

Despite the great number of grey seals killed each year in the Baltic, no detailed analyses have been made of their food. Of course, fish is the staple food, and fishermen report herring, cod, salmon, and eel among the species which grey seals have preyed upon in nets. In a shot grey seal a fisherman found twenty-seven eels all intact and all apparently swallowed at about the same time. But although the Baltic grey seal damages fishing nets, there are no data as to its real effect on fisheries within the Baltic sea area.

Hewer (1964) has tried to make a provisional life-table of the Atlantic grey seal, based on the population structure of this species applied to the pregnancy and mortality rates of the northern fur seal Callorhinus ursinus (cf. Kenyon and Scheffer, 1954). If we use the same method for the Baltic population of grey seals, based on an annual birthrate of 500 calves and without any human predation, we reach the following hypothetical composition at the end of the breeding season : 
Cows :-

Breeding . . . . . . 500

Of breeding age but non-pregnant . $\quad 125$

Mature but nulli-parous. . . . 53

Immature . $\quad . \quad$. $\quad . \quad$. 287

Bulls :-

Mature and territorial . . . . 66

Mature but non-territorial . $\quad . \quad 173$

Immature . . . . . . 340

$\begin{array}{lllll}\text { Idle or senile } \quad . \quad & . & . & . & .\end{array}$

Moulters :-

$-\frac{580}{1,545}$

(both sexes) . . . . . . . . 425

$$
\overline{1,970}
$$

In relation to the numbers of grey seals killed this hypothetical population size seems very low. But even if we increase the population figures by 100 per cent we only get 3,940, which is still very low.

\section{Acknowledgments}

The author is most grateful to Mr. Tauno V. Mäki of the Ministry of Agriculture, Helsinki, and to Dr. Göran Bergman, Zoological Institute of the University of Helsinki, for valuable statistical information.

\section{LITERATURE CITED}

BERGMAN, G., 1956. Sålbeståndet vid våra kuster. Nordenskiöld - samfundets tidskrift, 1956, pp. 49-65.

CURRY-LiNDAHL, K., 1963 Djuren i färg - däggdjur, kräldjur, groddjur, 3rd ed. Stockholm.

Davies, J. L. Observations on the grey seal (Halichoerus grypus) at Ramsey Island, Pembrokeshire. Proceedings of the Zoological Society of London, 119 : 673-692.

DaviEs, J. L., 1957. The geography of the grey seal. Fournal of Mammalogy, $38: 297-310$.

Haglund, B., 1961 . Säl. 200 pp. Stockholm.

HEwER, H. R., 1957. A Hebridean colony of the grey seal, Halichoerus grypus (Fab.) with comparative notes on the grey seals of Ramsey Island, Pembrokeshire. Proceedings of the Zoological Society of London, 128: 23-66.

Hewer, H. R, 1964. The determination of age, sexual maturity, longevity and a life-table in the grey seal (Halichoerus grypus). Proceedings of the Zoological Society of London, 142 : 593-624.

Lockley, R. M., 1954. British Mammals. The Atlantic grey seal. ORYX, 2 : 384-387.

SCHEFFER, V. B., 1958. Seals, Sea Lions and Walruses. Stanford. 